\title{
Entrepreneurial Risk Perception and Entrepreneurial Decision: the Moderating Effect of Entrepreneurial Self-efficacy
}

\author{
(SUBMITTED BUT NOT PRESENTED)
}

\author{
MA Kunshu \\ School of Management \\ Southwest University for Nationalities, SWUN \\ Chengdu, China \\ suzy.m@126.com
}

\author{
YAN Botao \\ School of Management \\ North China Institute of Science and Technology, NCIST \\ Beijing(east), China \\ beryan@qq.com
}

\begin{abstract}
Entrepreneurial self-efficacy plays a significant role in entrepreneurial behavior process, which attracts more and more academic attention but keep its influence mechanism to be further discovered. The influence of entrepreneurial selfefficacy on entrepreneurial risk decision is discussed based on entrepreneurial decision and entrepreneurial self-efficacy related theories. This empirical study demonstrates that: i) entrepreneurial self-efficacy has positive effect on entrepreneurial decision; and ii) entrepreneurial self-efficacy has moderating effect on entrepreneurial risk propensity and entrepreneurial decision.
\end{abstract}

Keywords-entrepreneurial risk perception; entrepreneurial self-efficacy; entrepreneurial decision making

\section{INTRODUCTION}

Cognitive theory attracts more attention and emphasizes the exploratory power of cognitive factors on entrepreneurial behavior because of the lack of exploratory power of trait theory on entrepreneurial activities from the viewpoint of entrepreneurial research process [1, 2]. Self-efficacy was introduced into entrepreneurial research field by entrepreneurial scholars in late 20th century, and entrepreneurial self-efficacy was defined. From then on more and more researches focus on individual entrepreneurial selfefficacy, that is how entrepreneurial self-efficacy influences entrepreneurial behavior and entrepreneurial performance [3].

On the one hand, the current researches on entrepreneurial self-efficacy mainly focus on the subjects in later period of entrepreneurial process, such as its effect on entrepreneurial performance. There are few of researches probe into the effect of entrepreneurial self-efficacy in the early period of entrepreneurship [5], but they mainly focus on its effect on entrepreneurial intention [6, 7]. Meanwhile, it is not clear that how entrepreneurial self-efficacy come into being. On the other hand, starting with individual perception on entrepreneurial risks, researches on entrepreneurial cognition probes into entrepreneurial decision making, and confirms that entrepreneurial risk perception does influence entrepreneurial decision making[8-11]. However, the effect of entrepreneurial self-efficacy on entrepreneurial decision making has not

Sponsored by NCIST Education Research HKJY201416. attracted broad attention, which deserves further studying [12].

Consequently, this paper focuses on the effect of entrepreneurial self-efficacy on entrepreneurial decision making in the early period of entrepreneurship process based on entrepreneurial risk perception and entrepreneurial behavior related research findings.

\section{THEORIES AND HYPOTHESES}

\section{A. Entrepreneurial Self-efficacy and Entrepreneurial Decision Making}

Self-efficacy is the extent or strength of one's belief on his own ability to complete the task and achieve the goal [13]. This concept derives from the concept of Self-Efficacy, which originated from social cognitive theory and social study theory and was firstly put forward by Albert Bandura, a famous psychologist. Scholars such as Chen introduced Self-efficacy into the field of entrepreneurship research, and then the concept of Entrepreneurial Self-Efficacy was put forward [3]. After that entrepreneurial self-efficacy related researches appear and increase. No matter entrepreneurial self-efficacy is defined as "entrepreneur's belief on the efficient accomplishment of entrepreneurial activities and achievement of success" [14, 15], or "individual confidence on the successful roles playing and implementing all entrepreneurial tasks" $[6,16]$ ' the consensus on the definition of entrepreneurial self-efficacy comes into being that it emphasizes individual confidence on engaging in entrepreneurial actions.

Entrepreneurial self-efficacy has impact on cognition and attitude in the process of entrepreneurial decision making, which was admitted by a lot of scholars [6, 17]. The more entrepreneurial self-efficacy an entrepreneur has, the more likely he undertakes entrepreneurial actions, therefore entrepreneurs show high-level of entrepreneurial self-efficacy [19]. Some Chinese scholars also find that entrepreneurial selfefficacy has some impact on entrepreneurial decision making of nascent entrepreneurs [20]. According to the theory of entrepreneurial self-efficacy, the more powerful entrepreneurial self-efficacy an individual has, the more confident he is to 
undertake a certain action. He is also more likely to undertake this action [13]. Thus, the following hypothesis is put forward:

$H_{l}$ : The higher of individual entrepreneurial self-efficacy is, the more likely he decides to start a startup when making an entrepreneurial decision.

\section{B. Entrepreneurial Risk Perception and Entrepreneurial Decision Making}

The risk perception of one person is similar with those of others in the same scenery, which is the presumption of decision making in economics (Nutt, 1986, 1993, see [7]). In fact, one's judgment on the risk of decision making significantly differs from another's [21]. One cannot comprehensively search and get all information required when making a decision because of the limitation of time and vigor. Besides, the obtained information of one person differs from another's because of different individual ability on information searching. Furthermore, even if different individuals get same information, the individual cognitive ability to interpret information differs from each other, resulting in different individual perceptions [22]. Therefore, the presumption of the research on entrepreneurial risk perception is that the risk perception of entrepreneurs differs from that of others [23]. There are a lot of scholars doing their research on entrepreneurial decision making from the point of entrepreneurial risk perception.

Individual perceived risk has negative behavior decision making, that is, the more risks one perceives, the more likely he chooses behavior avoidance, which can be found in classical economics theory, behavioral decision theory, and the developing entrepreneurship theory[8-11]. This argument is completely in conformity with another presumption in economics: one prefers to avoid risks. The more risks one perceives when making an entrepreneurial decision, the more likely he abstains from entrepreneurship when making a decision for the sake of avoiding perceived entrepreneurial high-risk [8-11].

$\mathrm{H}_{2}$ : The higher one perceives entrepreneurial risks, the less likely he decides to start a start-up when making an entrepreneurial decision.

\section{The Impact of Entrepreneurial Self-efficacy on Entrepreneurial Risk Perception and Entrepreneurial Decision}

This paper mainly probes into the impact of entrepreneurial self-efficacy on entrepreneurial risk perception and entrepreneurial decision. As mentioned before, on the one hand, the individual perception on risk inhibits entrepreneurial decision making [8-11], on the other hand, the individual confidence on his entrepreneurial ability significantly influences entrepreneurial behavior [24]. Individual entrepreneurial self-efficiency has impact on individual perception, promoting entrepreneurial behavior generation [20], and the higher one's entrepreneurial self-efficiency is, the higher his entrepreneurial behavior is[25], according to selfefficiency theory. That is, one has more confidence with his entrepreneurial ability when he has higher entrepreneurial selfefficiency. At this moment, even if one perceives high entrepreneurial risk, his entrepreneurial risk perception negatively impacting on entrepreneurial decision making is weakened because that high individual entrepreneurial selfefficiency weakens the impact of entrepreneurial risk perception on entrepreneurial decision making. On the contrary, one has less confidence on his entrepreneurial ability when he has lower entrepreneurial self-efficiency. At this point, entrepreneurial risk perception has significantly negative impact on entrepreneurial decision making. Therefore the following hypothesis is put forward:

$H_{3}$ : Entrepreneurial self-efficiency moderates the entrepreneurial risk perception and entrepreneurial decision making.

\section{MethodolOGIES}

\section{A. Research Design}

A scenario simulation based questionnaire survey is adopted in this paper with building a scenario of entrepreneurial decision making in a questionnaire. The Chinese scenario materials, being used by Simon etc. [8] and Keh etc. [8] in their research, were firstly translated into Chinese and then into English many times for consistency by professional translators from English major and doctor students engaging in entrepreneurship research. These materials were modified and adjusted many times during the process of focus group interviews and depth interviews when the interviewees were asked to give some advices on them for the purpose of being easily read and understood. The scenario materials were finally finished with content validity.

The decision making task was presented in written materials. The protagonist in this scenario is a successful manager "Miss/Mr. Tang" who has rich management experiences and entrepreneurial intention. He/she was asked to make a corresponding decision after reading these materials.

\section{B. Test Samples}

The samples are from Sichuan, Guangdong, Fujian, Anhui, Jiangsu, Shanghai, Hubei, etc. 300 questionnaires were issued and 272 were retrieved, among which 243 questionnaires are valid after deleting those missing blanks and/or wrongly filled out. The effective retrieving rate is $81 \%$. See Table I.

TABLE I. SAMPLES INFORMATION

\begin{tabular}{cccc}
\hline \multicolumn{2}{c}{ Demographic Variables } & Frequency & Percentage $(\%)$ \\
\hline \multirow{3}{*}{ Gender } & Male & 132 & 54.30 \\
& Female & 111 & 45.70 \\
& under 20 years & 4 & 1.65 \\
& 20-24 years & 96 & 39.51 \\
& 25-29 years & 72 & 29.63 \\
\multirow{4}{*}{ Age } & 30-34 years & 53 & 21.81 \\
& 35-44 years & 17 & 7.00 \\
& above 45 years & 1 & 4.12 \\
\hline
\end{tabular}




\section{Measurement of Related Variables}

All scales are 10-Point Likert Scales. Zhao etc.'s scales with 4 items [18] are adopted to measure entrepreneurial selfefficacy, among which, 1 represents no confidence, and 10 represents full of confidence. The measurement to risk perception involves in tools that are widely used in research (e.g. Simon, 1999; Mac Crimmon and Wehrung, 1990; Nutt, 1966, 1993; Thomas and McDaniel, 1990). The participant is required to perceive and evaluate entrepreneurial risks when he is in the scenario that the manager "Miss/Mr. Tang" is to make an entrepreneurial decision. The scale has five items, with 1 on behalf of the lowest degree of individual perceived entrepreneurial risk and 10 on behalf of the highest degree of individual perceived entrepreneurial risk. The scale on entrepreneurial decision making adopts the research scale of Simon etc. [8], with four items included. The score represents the possibility of individual description on entrepreneurial decision making and implementation, with 1 on behalf of the lowest possibility and 10 on behalf of the highest possibility.

After a test-retest of a two-week hiatus, all items in the questionnaire meet the requirement of reliability on internal consistency and test-retest reliability. Some enterprise managers, entrepreneurs, seniors and third year masters were asked to check all items before large-scale survey. The wordings in a few of items were revised to be more understandable. The final scale, revised many times, has a certain face validity and content validity.

The Cronbach aof entrepreneurial self-efficacy, entrepreneurial risk perception and entrepreneurial decision making is $0.93,0.84$ and 0.88 , respectively. The KMO of them is $0.86,0.84$ and 0.83 , respectively. See Table II for factor loading values and interpretation.

TABLE II. FACTOR ANALYSIS ON VARIABLES

\begin{tabular}{cccccc}
\hline Variables & KMO & Item & $\begin{array}{c}\text { Factor } \\
\text { loading }\end{array}$ & Interpretation & Cronbach's $a$ \\
\hline & & SE1 & 0.90 & & \\
Entrepreneurial & $0.86^{* * * *}$ & SE2 & 0.91 & & 0.93 \\
self-efficacy & & SE3 & 0.90 & $82.00 \%$ & \\
& & SE4 & 0.92 & & \\
Entrepreneurial & $0.83 * * *$ & RP3 & 0.82 & $61.56 \%$ & 0.84 \\
risk perception & & RP1 & 0.78 & & \\
& & RP4 & 0.77 & & \multirow{2}{*}{0.88} \\
& & RP5 & 0.78 & & \\
Entrepreneurial & $0.83 * * *$ & D1 & 0.88 & & \\
decision making & & D2 & 0.85 & $73.66 \%$ & a. ***P<0.001
\end{tabular}

\section{Analysis Tool}

The statistical data analysis was finished via SPSS13.0.

\section{RESUlTS AND ANALYSIS}

A. The impact of Entrepreneurial Self-efficacy, Entrepreneurial Risk Perception on Entrepreneurial Decision Making

Table III shows the result of regression analysis on hypotheses. Among which, the regression analysis of entrepreneurial self-efficacy and entrepreneurial decision making shows significantly positive correlation $(\mathrm{r}=0.574$, $\mathrm{P}<0.001$ ), which means that entrepreneurial self-efficacy has positive impact on entrepreneurial decision making and support hypothesis 1: The higher of individual entrepreneurial selfefficacy is, the more likely he choose to undertake entrepreneurship when making an entrepreneurial decision. The regression analysis of entrepreneurial risk perception and entrepreneurial decision making are negative correlation ( $\mathrm{r}=$ $0.499, \quad \mathrm{P}<0.001$ ), supporting hypothesis 2 : The higher one perceives entrepreneurial risks, the less likely he decides to start a start-up when making an entrepreneurial decision. The hypothesis is tested again.

TABLE III. THE RELATIONSHIP OF ENTREPRENEURIAL SELF-EFFICACY, RISK PERCEPTION AND DECISION MAKING

\begin{tabular}{|c|c|c|c|c|c|c|}
\hline & \multicolumn{3}{|c|}{ HI } & \multicolumn{3}{|c|}{$\mathrm{H}^{2}$} \\
\hline & $\begin{array}{l}\text { Correlation } \\
\text { Coefficient }\end{array}$ & $\begin{array}{l}\text { Standardized } \\
\text { Correlation } \\
\text { Coefficient }\end{array}$ & $t$ & $\begin{array}{l}\text { Correlation } \\
\text { Coefficient }\end{array}$ & $\begin{array}{l}\text { Standardized } \\
\text { Correlation } \\
\text { Coefficient }\end{array}$ & $t$ \\
\hline $\begin{array}{c}\text { Entrepreneurial } \\
\text { self-efficacy }\end{array}$ & 0.542 & $0.574 * * *$ & 10.88 & & & \\
\hline $\begin{array}{l}\text { Entrepreneurial risk } \\
\text { perception }\end{array}$ & & & & $-0.540 * * *$ & -0.499 & -8.94 \\
\hline $\mathrm{F}$ & & & 118.35 & & & 79.97 \\
\hline $\mathrm{R}^{2}$ & & & 0.329 & & & 0.249 \\
\hline Adjusted $\mathrm{R}^{2}$ & & & 0.327 & & & 0.246 \\
\hline
\end{tabular}

\section{B. The Moderating Effect of Entrepreneurial Self-efficacy on Entrepreneurial Risk Perception and Decision Making}

Moderating effect means that the causality of two variables is the function of the moderating variable, according to Baron and Kenny [28], and Sharma etc.[29]. One test method on moderating effect is to test the influence of interaction between independent variable and moderating variable on dependent variable. If the influence is significant, then the moderating effect works [28, 29]. The analysis results are in Table IV. The tolerance of every independent variable in regression equation is higher than 0.1 , and all variance inflation factors are less than 5, so it can be concluded that multiple comparison does not exist among all independent variables. The result shows that the interaction of entrepreneurial self-efficacy and risk perception significantly moderates entrepreneurial decision $(\mathrm{r}=0.183, \mathrm{P}<0.05)$ and shows that the moderating effect of entrepreneurial perception and decision making on entrepreneurial self-efficacy is significant. Therefore, the hypothesis was proved: Entrepreneurial self-efficiency moderates the entrepreneurial risk perception and entrepreneurial decision making. 
TABLE IV. THE MODERATING EFFECT OF ENTREPRENEURIAL SELFEFFICACY ON ENTREPRENEURIAL RISK PERCEPTION AND DECISION MAKING

\begin{tabular}{|c|c|c|c|c|c|c|c|c|}
\hline & $\begin{array}{l}\text { Correlation } \\
\text { Coefficient }\end{array}$ & $\begin{array}{l}\text { Standardized } \\
\text { Correlation } \\
\text { Coefficient }\end{array}$ & $\begin{array}{c}t \\
\text { value }\end{array}$ & tolerance & $V I F$ & $\begin{array}{c}F \\
\text { value }\end{array}$ & $R^{2}$ & $\begin{array}{c}\text { Adjusted } \\
\qquad R^{2}\end{array}$ \\
\hline $\begin{array}{l}\text { entrepreneurial } \\
\text { risk perception }\end{array}$ & -0.50 & $-0.47 * * *$ & $\begin{array}{c}- \\
7.34\end{array}$ & 0.33 & 3.07 & & & \\
\hline $\begin{array}{l}\text { entrepreneurial } \\
\text { self-efficacy } \\
\text { entrepreneurial } \\
\text { self-efficacy } \times\end{array}$ & 0.31 & $0.33^{* * *}$ & 3.95 & 0.53 & 1.84 & & & \\
\hline
\end{tabular}

$71.110 .47 \quad 0.46$

risk perception

\section{CONCLUSIONS AND Discussions}

The contribution of this research includes: (1) introducing the cognitive factor of entrepreneurial self-efficacy into entrepreneurial decision making process according to the theory of self-efficacy; (2) probing into the moderating effect of entrepreneurial self-efficacy on the relationship between entrepreneurial risk perception and entrepreneurial decision making.

\section{A. Main Effect Plot of Entrepreneurial Self-efficacy and Entrepreneurial Risk Perception}

As can be seen from table III, the main effect plot of entrepreneurial self-efficacy is significant $(\mathrm{r}=0.574, \mathrm{P}<0.001)$, accordingly, it can be deduced that entrepreneurial self-efficacy remarkably affects entrepreneurial decision making, that is, the individual with high entrepreneurial self-efficacy is more likely to start a startup than those with lower entrepreneurial selfefficacy. This indicates that entrepreneurial self-efficacy has positive impact on entrepreneurial behavior.

As also can be seen from Table III, the main effect plot of entrepreneurial risk perception $(\mathrm{r}=-0.499, \quad \mathrm{P}<0.001)$, accordingly, it can be deduced that entrepreneurial risk perception affects entrepreneurial decision making, that is, the individual with high entrepreneurial risk perception is less likely to take entrepreneurial action than those with lower entrepreneurial risk perception. A previous research result was confirmed: entrepreneurial risk perception negatively affect entrepreneurial decision making[8-11] 。 The previous entrepreneurial research confirmed the basic assumption : Individual entrepreneurial risk perception differs from another during the process of entrepreneurial action [22] .

\section{B. The Moderating Effect of Entrepreneurial Self-efficacy on Entrepreneurial Risk Perception and Decision Making}

Table IV shows the significant moderating effect of entrepreneurial self-efficacy on entrepreneurial risk perception and decision making. Fig.l visually shows that the relationship between entrepreneurial risk perception and decision making will differ with the degree of entrepreneurial self-efficacy. The straight line (see the full line in Fig.1) on behalf of the relationship between entrepreneurial risk perception and decision making is gentler when an individual has high entrepreneurial self-efficacy, which indicates that the

confidence of individual entrepreneurial ability is the determinant of entrepreneurial decision making when he has high entrepreneurial self-efficacy [23]. High entrepreneurial self-efficacy significantly weakens the negative effect of entrepreneurial risk perception on entrepreneurial decision making, so that the negative effect of entrepreneurial risk perception is not remarkable. On the other hand, entrepreneurial self-efficacy has less impact on the relationship between entrepreneurial risk perception and entrepreneurial decision making and cannot moderate it when an individual has low entrepreneurial self-efficacy. In this case, behavioral decision theory works and effectively explains the negative relationship between entrepreneurial risk perception and decision making [8-11].

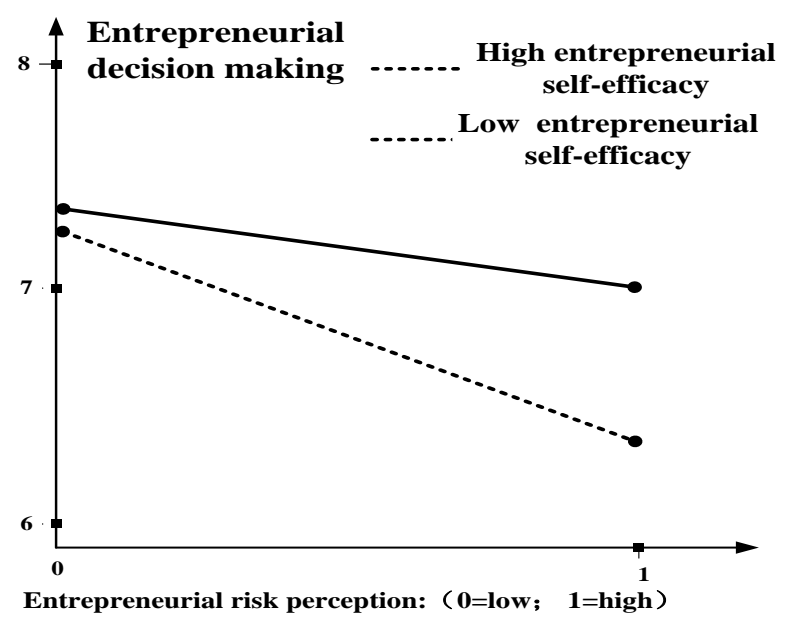

Fig. 1. The moderating effect of entrepreneurial self-efficacy on entrepreneurial risk perception and decision making

\section{Conclusions and Limitations}

The following conclusions come into being: (1) entrepreneurial self-efficacy has positive effect on entrepreneurial decision making; (2) entrepreneurial selfefficacy partially moderate entrepreneurial risk perception and decision making. The impact of entrepreneurial risk perception on entrepreneurial decision making has been weakened with secondary influence when he has high entrepreneurial selfefficacy. However, entrepreneurial self-efficacy entrepreneurial risk perception significantly suppresses entrepreneurial decision making when one has low entrepreneurial selfefficacy.

This research discusses and tests the positive effect of entrepreneurial self-efficacy on entrepreneurial decision, and its moderating effect on entrepreneurial decision making. Entrepreneurial self-efficacy plays an important role in the process of entrepreneurial decision making, which not only directly enhances the generation of entrepreneurial behavior, but also influences the relationship between entrepreneurial risk perception and entrepreneurial decision making, which also significantly restrain the negative effect on entrepreneurial decision making especially when an individual has high entrepreneurial self-efficacy. This has positive influence on the entrepreneurial decision making on those creative and high-risk 
projects. Once individual entrepreneurial self-efficacy is effectively enhanced, the negative effect of entrepreneurial risk on entrepreneurial behavior is well weakened, which promotes the individual to actively put creative ideas into action and create a new start-up advancing entrepreneurial activity.

The research has some limitations. The action range of entrepreneurial self-efficacy needs to be expanded. Entrepreneurial self-efficacy may be introduced into other actions in the prior period of entrepreneurial activity, such as the identification of entrepreneurial opportunity, so as to better understand the effect of entrepreneurial self-efficacy on entrepreneurial behavior. Furthermore, a source trace on entrepreneurial self-efficacy needs to be done in the future research.

\section{REFERENCES}

[1] Sitkin, S. B., Pablo, A. L., "Reconceptualizing the determinants of risk behavior," Academy of Management Review, vol. 17, pp. 9-38. January 1992.

[2] Carter, N. M., Gartner, W. B., Shaver, K. G., Gatewood, E. J., "The career reasons of nascent entrepreneurs," Journal of Business Venturing, vol. 18, pp. 13- 39, January 2003.

[3] Chen, C. C, Greene, P G., Crick, A., "Does entrepreneurial self-efficacy distinguish entrepreneurs from manager? "Journal of Business Venturing, vol. 13, pp. 295-316, April 1998.

[4] Hmieleski, K. M., Corbett, A. C., "The contrasting interaction effects of improvisational behavior with entrepreneurial self-efficacy on new venture performance and entrepreneur work satisfaction," Journal of Business Venturing, vol. 23, pp. 482- 496, April 2008

[5] Drnovšek, M., Wincent, J., Cardon, M. S. , "Entrepreneurial selfefficacy and business start-up: developing a multi-dimensional definition," International Journal of Entrepreneurial Behaviour \& Research, vol. 16, pp. 329-348., Aril 2010.

[6] Boyd, N G., and Vozikis, G S., "The influence of self-efficacy on the development of entrepreneurial intentions and actions," Entrepreneurship: Theory and Practice, vol. 18, pp. 63-77, April 1994.

[7] LIU Wanli, HU Pei, XU Kunpeng, "Can Entrepreneurial Opportunities really Help Entrepreneurship Intentions? A Study based on Mixing Effect of Entrepreneurship Self-efficacy and Perceived Risk," Nankai Business Review, vol. 14, pp. 83-90, May 2011.

[8] Simon, M., Houghton, S.M., Aquino, K., "Cognitive biases, risk perception, and venture formation: how individuals decide to start companies," Journal of Business Venturing, vol. 15, pp. 113-134, February 1999.

[9] Forlani, D., Mullins, J. W., "Perceived risks and choices in entrepreneurs' new venture decisions," Journal of Business Venturing, vol. 15, pp. 305-322, April 2000.

[10] Keh, H. T., Foo, M. D., Lim, B. C., "Opportunity evaluation under risky conditions: The cognitive processes of entrepreneurs," Entrepreneurship: Theory and Practice, vol. 27, pp. 125-148. February 2002.

[11] Geldren M. V., Thurik R., Bosma N., "Success and risk factors in the pre- startup phase," Small business economics, vol. 26, pp. 365- 380, April 2006.

[12] MA Kunshu, HU Pei, QIN Rongfang, "Review on Entrepreneurship Self-efficacy," Foreign Economics \& Management, vol. 30, pp. 59-64, December 2008.
[13] Bandura, A. Social foundations of thought and action: A social-cognitive view, Englewood Cliffs, NJ: Prentice-Hall. 1986, pp. 35-76.

[14] Gist, M E, Mitchell, T R., "Self-efficacy: a theoretical analysis of its determinants and malleability," Academy of Management Review, vol. 17, pp. 183-211, February 1992.

[15] Krueger N. Jr., Dickson P. R., "How believing in ourselves increases risk taking: perceived self-efficacy and opportunity recognition," Decision Sciences, vol. 25, pp. 385-400, March 1994.

[16] Altuntaş, G., Sözüer, A., Doğan, A., Demirtaş, H. T. , "The role of work hope on entrepreneurial self-efficacy and entrepreneurial intentions: evidence from business students in Turkey," International Conference on Economic and Social Studies, vol. 1, Yugoslavia :Sarajevo, 2013, pp. $10-11$.

[17] Cooper, A.C., Folta, T. b., Woo, C., "Entrepreneurial information search," Journal of Business Venturing, vol. 10, pp.107-120, February 1995.

[18] Zhao, Hao, Seibert, S E, Hills. G E., "The mediating role of self-efficacy in the development of entrepreneurial intentions," Journal of Applied Psychology, vol. 90, pp. 1265-1 272, June 2005.

[19] Spiegel, O., Abbassi, P., Schlagwein, D., Fischbach, K., "Going it all alone in web entrepreneurship: a comparison of single founders vs. cofounders," Proceedings of the 2013 annual conference on Computers and people research, vol. 1, United States: Cincinnati, pp. 384-409.

[20] TANG Jing, JIANG Yanfu, "The Career Choice of Nascent Entrepreneurs: An Entrepreneurial Self-efficacy Perspective," Science of Science and Management of S.\& T. , vol 10, pp. 180-185, October 2007.

[21] Weber, E.U., Anderson, C.J., Birnbaum, M.H., "A theory of perceived risk and attractiveness," Organizational Behavior and Human Decision Processes. vol. 52, pp. 492-523., March 1992.

[22] Veld, C., Veld-Merkoulova, Y, V., "The risk perceptions of individual investors", Journal of Economic Psychology, vol. 29, pp. 226-252, February 2008.

[23] Koellinger, P., Minniti, M., Schade, C. "'I think I can, I think I can': Overconfidence and entrepreneurial behavior," Journal of Economic Psychology, vol. 28, pp. 502-527, April 2007.

[24] Wood, R., Bandura, A., "Social cognitive theory of organizational management," Academy of Management Review, vol. 14, pp. 361-384, March 1989.

[25] Hmieleski, K. M. Corbett, A. C., "The contrasting interaction effects of improvisational behavior with entrepreneurial self-efficacy on new venture performance and entrepreneur work satisfaction," Journal of Business Venturing, vol. 23, pp. 482-496, April 2008.

[26] Irena, M. K., Gordana, Ć, "Changes in entrepreneurial self-efficacy since completion of entrepreneurial studies",Procedia-Social and Behavioral Journal, unpublished..

[27] Sitkin. S. B., Weingart. L. R., "Determinants of risk decision-making behavior: A Test of the Mediating Role of Risk Perception and propensity," Academy of Management Journal, vol. 38, pp. 1573-1592, June 1995.

[28] Baron, R. M., Kenny, D. A., "The moderator-mediator variable distinction in social psychological research: conceptual, strategic, and statistical considerations", Journal of Personality and Social Psychology, vol. 51, pp. 1173-1182., June 1986.

[29] Sharma, S., Durand, R. M., Gur-Arie, O., "Identification and analysis of moderator variables," Journal of Marketing Research, vol. 18, pp. 291300, August 1981.

[30] WANG Baojin, SPSS and Behavioral Science Research. Beijing: Peking University Press, 2007, pp. 106-112. 